\title{
Peningkatan hasil belajar PPKn melalui metode make a match kelas XII SMA Muhammadiyah 2 Yogyakarta
}

\section{Eny Widyastuti}

SMA Muhammadiyah 2 Yogyakarta. Jl. Kapas No.7, Semaki, Umbulharjo, Kota Yogyakarta, Daerah Istimewa Yogyakarta 55166, Indonesia enywidya1982@gmail.com

* corresponding author

\section{ARTICLE INFO}

Keywords

Pembelajaran PPKn

Make a match

Hasil belajar

\begin{abstract}
Penelitian ini bertujuan untuk meningkatkan hasil belajar siswa dengan penerapan metode pembelajaran Make A Match pada siswa kelas XII IPS 2 di SMA Muhammadiyah 2 Yogyakarta. Jenis penelitian ini adalah penelitian tindakan kelas yang terdiri atas 2 siklus, dimana setiap siklus terdapat dua kali pertemuan. Subjek penelitian adalah siswa kelas XII IPS 2 yang berjumlah 20 siswa. Pemilihan subjek penelitian dilakukan karena nilai rata-rata kelas tersebut yang paling dibandingkan dengan kelas-kelas yang lain. Teknik pengumpulan data mrnggunakan tes, observasi, wawancara, catatan lapangan. Berdasarkan hasil data yang sudah dianalisis metode pembelajaran Make A Match dapat meningkatkan hasil belajar siswa. Peningkatan hasil belajar siswa terlihat dari nilai rata-rata kelas siklus I adalah 78,15 dan terdapat 55\% siswa sudah mencapai KKM, pada siklus II nilai rata-rata kelas adalah 83,15 dan terdapat $75 \%$ siswa yang sudah mencapai KKM sehingga indikator keberhasilan individu dan kelas telah terpenuhi pada akhir siklus kedua. Berdasarkan hasil analisis dapat dijelaskan bahwa penerapan pembelajaran dengan metode Make A Match dapat meningkatkan kemampuan hasil belajar.
\end{abstract}

This is an open access article under the CC-BY-SA license.

\section{PENDAHULUAN}

Salah satu usaha meningkatkan kualitas SDM adalah dengan meningkatkan pendidikan. Hal ini sesuai dengan salah satu tujuan negara yaitu mencerdaskan kehidupan bangsa. Pendidikan adalah sebagai upaya yang sangat dibutuhkan dan memiliki kontribusi yang sangat besar terhadap kemajuan suatu negara. Pendidikan yang berkualitas bagus akan sangat menentukan bagaimana keadaan dan kemajuan suatu negara. Pendidikan sebagai upaya yang sangat dibutuhkan dan memiliki kontribusi yang sangat besar terhadap kemajuan suatu Negara. Kegiatan antara guru dan siswa dalam pendidikan biasa disebut dengan proses pembelajaran. Proses pembelajaran dapat diberi arti sebagai sebuah upaya yang sistematis dan disengaja oleh pendidik untuk menciptakan kondisi-kondisi agar peserta didik melakukan kegiatan belajar mengajar. Dalam kegiatan pendidikan terjadi kegiatan interaktif edukatif antara dua pihak (D. Sudjana, 2001). Proses pembelajaran yang terjadi harus berpusat pada siswa, siswa tidak berinteraksi hanya kepada guru sebagai salah satu sumber belajar, tetapi berinteraksi dengan keseluruhan sumber belajar yang ada sehingga bisa dipakai untuk mencapai tujuan pembelajaran. Pembelajaran yang berpusat pada siswa lebih meningkatkan partisipasi siswa di dalam proses pembelajaran (Asani, 2012). 
Namun berdasarkan data penilaian diketahui bahwa hasil belajar siswa masih rendah. Rendahnya hasil belajar siswa terlihat dari nilai rata-rata ulangan harian semester 1 mata pelajaran PPKn sebesar 56,5 dimana nilai tersebut masih di bawah nilai kriteria ketuntasan minimal (KKM) yaitu sebesar 76 . Rendahnya nilai tersebut bisa menjadikan indikator bahwa proses pembelajaran yang berlangsung tidak bisa berjalan dengan maksimal, hal ini dipengaruhi oleh berbagai macam permasalahan yang ada di dalam kelas antara lain siswa yang terlambat masuk kelas, tidak mengikuti kegiatan diskusi, kurang konsentrasi dalam mengikuti proses belajar, ramai di kelas, bermain Handphone, dan tidak mengerjakan tugas. Selain itu adanya persepsi negatif siswa bahwa PPKn kurang penting karena tidak termasuk mata pelajaran yang diuji dalam ujian nasional (Hermawan et al., 2018).

Sesuai dengan tuntutan Kurikulum 2013, guru telah berusaha menerapkan proses pembelajaran yang berpusat pada siswa dan mengharuskan partisipasi aktif dari siswa. Namun masih dirasakan bahwa proses pembelajaran tidak diikuti secara aktif oleh semua siswa, karena hanya beberapa siswa yang aktif melaksanakan kegiatan pembelajaran tersebut, hanya beberapa siswa yang aktif membaca, mencari sumber belajar, berdiskusi, bertanya ketika presentasi, bahkan banyak siswa yang tidak memperhatikan, sebagian siswa lain juga berbicara dengan temannya mengenai hal lain, siswa menjadi kurang mampu mengemukakan pendapat, malas bertanya, malas menjawab, dan tidak serius dalam proses pembelajaran, sehingga banyak siswa kadang merasa kesulitan menangkap materi yang di pelajari pada saat kegiatan belajar sedang berlangsung yang berakibat pada rendahnya hasil belajar siswa.

Untuk mengatasi permasalahan tersebut guru memilih metode pembelajaran yang mampu meningkatkan tingkat partisipasi aktif siswa, sehingga siswa menjadi lebih mudah memahami materi yang sedang dipelajari yang nantinya akan berimbas pada naiknya hasil belajar siswa. Salah satu metode pembelajaran yang bias meningkatkan tingkat partisipasi siswa biasa di sebut dengan Cooperative Learning. Pembelajaan kooperatif merupakan salah satu metode pembelajaran kelompok yang memiliki aturan-aturan tertentu (Wena, 2009). Salah satu metode pembelajaran cooperative learning adalah pembelajaran metode make a match (Wahyuningsih et al., 2019). Metode pembelajaran dimana guru menyiapkan kartu yang berisi soal atau permasalahan dan menyiapkan kartu jawaban kemudian siswa mencari pasangan kartunya. Metode pembelajaran make a match yaitu pembelajaran yang metode mengajarnya dengan mencari pasangan melalui kartu pertanyaan dan jawaban yang harus ditemukan dan didiskusikan oleh pasangan siswa tersebut. Metode ini bisa dijadikan sebagai salah satu alternatif yang dapat diterapkan untuk meningkatkan hasil belajar siswa. Metode pembelajaran make a match adalah pembelajaran menggunakan kartu-kartu (Nurwidia et al., 2019; Wahyuningsih et al., 2019). Kartu-kartu tersebut terdiri dari kartu yang berisi soal dan kartu yang lainnya berisi jawaban dari soal-soal tersebut. Kelebihan dari metode pembelajaran make a match adalah siswa mencari pasangan sambil belajar mengenai suatu konsep atau materi dalam suasana yang menyenangkan. Dengan penerapan metode pembelajaan make a match yang lebih meningkatkan partisipasi aktif siswa di harapkan bisa meningkatkan hasil belajar siswa.

Hasil belajar adalah perubahan tingkah laku yang diperoleh dari kegiatan belajar (Cagne, Coombs yang dikutip oleh D. Sudjana (2001). Perubahan tingkah laku sebagai hasil belajar itu mencakup ranah afeksi, kognitif dan psikomotor (Benyamin Bloom yang dikutip oleh (D. Sudjana, 2001). Hasil belajar pada dasarnya merupakan akibat dari suatu proses belajar, ini berarti bahwa optimalnya hasil belajar siswa tergantung pula pada proses belajar siswa dan proses mengajar guru (N. Sudjana, 2009). Hasil belajar merupakan perubahan perilaku peserta didik yang diperoleh setelah mengikuti pembelajaran selama kurun waktu tertentu yang relatif menetap. Menurut Surya (2004) menjelaskan bahwa hasil proses belajar ialah perubahan perilaku individu, individu akan memperoleh perilaku yang baru, menetap, fungsional, positif, disadari. Perubahan perilaku sebagai hasil pembelajaran ialah perilaku secara keseluruhan yang mencakup aspek kognitif, afektif, konatif dan motorik. Dari sisi guru, tindak mengajar diakhiri dengan proses evaluasi belajar. Dari sisi siswa, hasil belajar merupakan puncak dari proses belajar. Berdasarkan beberapa pendapat diatas hasil belajar adalah sebagai akibat dari sebuah proses pembelajaran yang, akibat dari proses bisa dalam bentuk perubahan perilaku ataupun perubahan pemahaman. Faktor-faktor yang mempengaruhi hasil belajar antara lain: Faktor dari luar diri siswa atau faktor lingkungan. Faktor lingkungan antara lain 
dipengaruhi oleh motivasi belajar, minat dan perhatian, sikap dan kebiasaan belajar, ketekunan, faktor fisik dan psikis (N. Sudjana, 2009).

Hasil belajar yang dapat diraih sangat tergantung dengan lingkungan, artinya ada faktor-faktor yang berada di luar dirinya yang dapat menentukan atau mempengaruhi hasil belajar yang di capai. Salah satu lingkungan belajar yang paling dominan mempengaruhi hasil belajar di sekolah adalah kualitas pengajaran. Yang dimaksud kualitas pengajaran ialah tinggi rendahnya atau efektif tidaknya proses belajar mengajar dalam mencapai tujuan pengajaran. Faktor dari dalam diri siswa. Menurut Caroll yang dikutip oleh N. Sudjana (2009) berpendapat bahwa hasil belajar yang dicapai oleh siswa dipengaruhi oleh lima faktor yaitu (a) bakat pelajar, (b) waktu yang tersedia untuk belajar, (c) waktu yang diperlukan siswa untuk menjelaskan pelajaran, dan (d) kemampuan individu. Berdasar-kan berbagai pendapat tentang hasil belajar diatas, banyak hal yang mempengaruhi hasil belajar baik dari dalam siswa, guru, lingkungan belajar dan sumber belajar.

Tujuan pendidikan yang ingin dicapai menurut N. Sudjana (2009) dapat dikategorikan menjadi tiga bidang yakni: Tipe hasil belajar bidang kognitif, meliputi; (1) Tipe hasil belajar pengetahuan hafalan (Knowledge); (2) Tipe hasil belajar pemahaman (Comprehention); (3) Tipe hasil belajar penerapan (aplikasi); (4) Tipe hasil belajar analisis; (5) Tipe hasil belajar sintesis; (6) Tipe hasil belajar evaluasi.

Tipe hasil belajar bidang afektif. Bidang afektif berkenaan dengan sikap dan nilai. Beberapa ahli mengatakan, bahwa sikap seseorang dapat diramalkan perubahannya, bila seseorang telah menguasai bidang kognitif tingkat tinggi. Tipe hasil belajar afektif tampak pada siswa dalm berbagai tingkah laku seperti atensi/perhatian terhadap pelajaran, disiplin, motivasi belajar, menghargai guru dan teman sekelas, kebiasaan belajar dan lain-lain. Ada beberapa tingkatan bidang afektif sebagai tujuan dan tipe hasil belajar. Tingkatan tersebut dimulai tingkat yang dasar/sederhana sampai tingkatan yang kompleks, tingkatannya yaitu: Receiving/attending, Responding atau jawaban, Valuing (penilaian), dan Organisasi.

Tipe hasil belajar bidang psikomotor. Hasil belajar bidang psikomotor tampak dalam bentuk ketrampilan (skill), kemampuan bertindak individu (seseorang). Ada 6 tingkatan ketrampilan yakni: (1) Gerakan refleks (ketrampilan pada gerakan yang tidak sadar); (2) Ketrampilan pada gerakangerakan kasar; (3) Kemampuan perceptual termasuk di dalamnya membedakan visual, membedakan auditif, motorik dan lain-lain; (4) Kemampuan di bidang fisik, misalnya kekuatan, keharmonisan, ketepatan; (5) Gerakan-gerakan skill, mulai dari ketrampilan sederhana sampai ketrampilan kompleks; (6) Kemampuan yang berkenaan dengan nondecursive komunikasi seperti gerakan ekspresif, interpretative. Tipe hasil belajar yang dikemukakan sebenarnya tidak berdiri sendiri, tetapi selalu berhubungan satu sama lain bahkan ada dalam kebersamaan.sebagai tujuan yang hendak di pakai ketiganya harus nampak sebagai hasil belajar siswa. Berdasarkan pendapat diatas, bisa menyimpulkan bahwa tipe hasil belajar ada tiga, yaitu kognitif, afektif dan psikomotor, tipe kognitif berkenaan dengan pengetahuan, afektif berkenaan dengan sikap dan nilai, sedangkan psikomotor berkenaan dengan ketrampilan dan kemampuan bertindak individu.

\section{METODE}

Penelitian ini adalah penelitian tindakan kelas (Classroom Action Research). Subjek penelitian ini adalah siswa kelas XII IPS 2 SMA Muhammadiyah 2 Yogyakarta tahun pelajaran 2016/2017 semester 1 dengan jumlah siswa 20 yang terdiri dari 12 siswa putra dan 8 siswa putri. Penelitian ini dilakukan dalam 2 siklus yang setiap siklusnya terdiri dari 2 pertemuan, setiap pertemuan selama $2 \mathrm{x}$ 45 menit. Dalam setiap siklus terdiri dari penyusunan rencana, tindakan, observasi, dan refleksi. Penjabaran kegiatan setiap siklusnya sebagai berikut: (1) Kegiatan Perencanaan, perencanaan kegiatan yang dilakukan yaitu menyusun RPP dengan metode make a match, menyusun dan mempersiapkan lembar observasi, membuat daftar pertanyaan wawancara, membuat soal tes siklus. (2) Kegiatan Pelaksanaan Tindakan dilakukan oleh guru dengan melaksanakan proses pembelajaran PPKn menggunakan metode make a match; (3) Kegiatan Observasi, kegiatan yang dilakukan oleh kolaborator untuk mengamati proses pelaksanaan pembelajan; (4) Kegiatan Refleksi, dilakukan berdasarkan temuan temuan, kemudian diadakan analisis data yang diperoleh dari dampak pelaksanaan 
tindakan dan hambatan yang muncul dan didiskusikan rencana berikutnya unuk memperbaiki halhal yang masih kurang.

Teknik pengumpulan data dalam penelitian ini adalah dengan tes, observasi, wawancara dan catatan pelaksanaan proses pembelajaran, dokumentasi foto dan video. Analisis data dilakukan dengan menyeleksi dan mengelompokkan data, memaparkan atau mendiskripsikan data dalam bentuk narasi, tabel dan atau grafik, serta menyimpulkan dalam bentuk pernyataan. Berdasarkan hasil analisis dilakukan refleksi, yaitu renungan, atau mengingat kembali apa yang sudah berhasil dikerjakan, mengapa berhasil. Berdasarkan hasil refleksi, guru melakukan perencanaan tindak lanjut, yang dapat berupa revisi dari rencana lama atau baru.

\section{HASIL DAN PEMBAHASAN}

\section{Deskripsi Siklus I}

Siklus I dilaksanakan dalam dua kali pertemuan. Pelaksanaan siklus I dijelaskan sebagai berikut:

\section{Perencanaan}

Pada tahap ini peneliti merancang tindakan yang akan dilakukan dalam penelitian: baik pada pertemuan satu dan pertemuan dua, perencanaan yang dilakukan pada pertemuan satu dan pertemuan dua hampir sama yaitu menyusun Rencana Pelaksanaan Pembelajaran dengan metode make a match, menyusun dan mempersiapkan lembar observasi mengenai pelaksanaan pembelajaran dengan metode make a match, membuat daftar pertanyaan wawancara yang berkaitan dengan proses pembelajaran metode make a match di kelas, membuat 10 kartu soal dan 10 kartu jawaban, untuk pertemuan kedua peneliti membuat soal tes untuk siklus I

\section{Pelaksanaan tindakan}

Kegiatan tindakan pada pertemuan satu membahas materi tentang hak warga negara dan kewajiban warga negara, sedangkan pada pertemuan kedua membahas materi tentang hak warga yang diatur dalam UUD 1945. Kegiatan diawali dengan membuka pelajaran, dilanjutkan dengan melakukan presensi siswa, guru kemudian melakukan apersepsi dan motivasi untuk mengulang sedikit materi pembelajaran minggu lalu tentang kekuasaan kehakiman. Pada kegiatan inti guru menyampaikan materi pengantar berkaitan dengan hak warga negara dan kewajiban warga Negara yang diatur dalam UUD 1945. Guru menjelaskan langkah-langkah dalam kegiatan pembelajaran metode make a match. Guru kemudian membagikan kartu berisi soal kepada saparuh siswa dan kartu berisi jawaban kepada separuh siswa yang lain berkaitan dengan materi tentang hak warga negara dan kewajiban warga negara. Kemudian guru akan memberikan waktu untuk siswa memikirkan jawabannya. Guru meminta siswa untuk menemukan pasangan dari kartu yang mereka pegang, siswa berlarian dan berteriak kepada temannya untuk mencari pasangan dari kartu yang mereka miliki. Siswa yang sudah menemukan pasangan kartunya akan berjejer di depan urut sesuai dengan siswa yang terlebih dahulu menemukan pasangannya. Setelah semua siswa menemukan pasangan kartu masing-masing, pasangan siswa yang pertama kali menemukan pasangan akan membacakan soal dan jawaban dari kartu tersebut kemudian siswa tersebut akan kembali ke tempat duduk mereka masing-masing. Setelah semua siswa membacakan soal dan jawaban dari kartu mereka masing-masing, guru akan mengocok kartu dan membagikan lagi pada siswa, dengan langkah yang sama seperti pada pembagian kartu yang pertama siswa diminta untuk menemukan pasangannya kembali, pada pertemuan pertama ini, kartu dikocok lalu dibagikan kepada siswa, kemudian mereka menemukan pasangannya sebanyak 9 kali putaran. Di akhir kegiatan guru membantu siswa untuk membuat kesimpulan dari materi yang sudah dipelajari. Untuk pertemuan kedua guru memberikan soal tes siklus I. Guru mengingatkan siswa untuk mempelajari materi yang akan dipelajari minggu depan. Guru menutup pelajaran dan mengucapkan salam.

\section{Observasi}

Observasi dilaksanakan selama pelaksanaan tindakan oleh kolaborator penelitian, kolaborator mengamati berdasarkan lembar observasi yang sudah dipersiapkan oleh peneliti. Berdasarkan observasi yang dilakukan oleh observer pada pertemuan satu dan dua, pertama kali siswa menjawab salam, dilanjutkan dengan menyiapkan buku tulis dan buku paket, lalu siswa mendengarkan 
penjelasan guru tentang apersepsi dan motivasi, siswa mendengarkan guru menyampaikan tentang tujuan pembelajaran, materi pengantar. Lalu siswa mendengarkan penjelasan guru tentang langkahlangkah dari pembelajaran metode make a match. Siswa mendapat satu buah kartu, lalu siswa memikirkan jawabannya, lalu siswa akan berlalu mencari pasangan kartu yang dimilikinya, siswa yang sudah menemukan pasangan kartunya akan berjajar di depan kelas, setelah semua siswa menemukan pasangan kartunya, maka siswa yang paling pertama menemukan pasangan akan membacakan pasangan kartunya di depan kelas, diikuti pasangan yang lainnya, sampai habis. Setelah itu kegiatan diawali lagi dari guru membagi kartu, sampai siswa membacakan isi dari kartu pasangannya. Pada pertemuan pertama ini, sebanyak 9 kali siswa melakukan kegiatan menemukan pasangan. Kegiatan selanjutnya adalah guru bersama-sama dengan siswa menyimpulkan materi pelajaran pada pertemuan itu, pada pertemuan kedua siswa mengerjakan soal yang sudah diberikan oleh guru, kemudian siswa mendengarkan penjelasan guru tentang tugas untuk pertemuan yang akan datang, lalu menjawab salam penutup dari guru. Refleksi

\section{Refleksi}

Berdasarkan hasil lembar observasi, wawancara dengan siswa dan diskusi dengan kolaborator hasil refleksi pada siklus I baik pada pertemuan satu dan pertemuan dua dapat didiskripsikan sebagai berikut: Penerapan pembelajaran metode make a match menjadikan siswa sangat aktif, karena semua siswa harus berfikir dan bergerak untuk mencari kartu pasangannya, banyak siswa mengalami kesulitan untuk menemukan pasangan kartunya, kesulitan yang dialami siswa dalam menemukan pasangan dikarenakan siswa belum memahami dan belum mengerti tentang materi yang dipelajari pada pertemuan saat itu. Supaya membantu pasangan lain memahami materi yang dipelajari pada pertemuan itu, maka siswa diharapkan mampu menjelaskan ke teman lain berdasarkan kartu yang mereka miliki.

\section{Deskripsi Siklus II}

Kegiatan pada siklus II untuk melanjutkan siklus I, dengan melakukan penyempurnaan atau perbaikan dari siklus sebelumnya. Pelaksanaan siklus II dilaksanakan dalam dua pertemuan, pada pertemuan pertama dan kedua diawali kembali dengan sebuah perencanaan, tindakan, observasi dan refleksi yang memperhatikan saran-saran atau masukan yang diperoleh dari refleksi siklus I. Siklus II dilaksanakan dalam dua kali pertemuan. Kegiatan dalam Siklus II dijelaskan sebagai berikut :

\section{Perencanaan Siklus II}

Rencana tindakan pada siklus ini sama seperti sikuls I yaitu: menyusun Rencana Pelaksanaan Pembelajaran dengan metode make a match, menyusun dan mempersiapkan lembar observasi mengenai pelaksanaan pembelajaran dengan metode make a match, membuat kartu soal dan kartu jawaban, pada pertemuan kedua ditambah dengan membuat soal tes siklus II

\section{Pelaksanaan tindakan Siklus II}

Kegiatan pada siklus II juga dilaksanakan dalam dua pertemuan, pada pertemuan pertama mempelajari materi tentang pelanggaran hak dan pengingkaran kewajiban, sedangkan pada pertemuan kedua mempelajari materi tentang upaya pencegahan dan penanganan pelanggaran hak dan pengingkaran kewajiban, kegiatan yang dilaksanakan hampir sama dengan pelaksanaan kegiatan siklus I diawali dengan membuka pelajaran, dilanjutkan dengan melakukan presensi siswa, guru kemudian melakukan apersepsi dan motivasi untuk mengulang sedikit materi pembelajaran pada minggu lalu. Guru menyampaikan tujuan pembelajaran yang akan dicapai pada pertemuan ini. Pada kegiatan inti guru menyampaikan materi pengantar. Guru menyiapkan kartu yang akan dibagikan kepada siswa dalam kegiatan pembelajaran metode make a match. Guru kemudian membagikan kartu berisi soal kepada saparuh siswa dan kartu berisi jawaban kepada separuh siswa yang lain. Kemudian guru akan memberikan waktu untuk siswa memikirkan jawabannya. Guru meminta siswa untuk mencari pasangan kartu yang mereka miliki. Siswa lalu berlarian dan berteriak pada temannya untuk mencari pasangan dari kartu yang mereka miliki. Siswa yang sudah menemukan pasangan kartunya akan berjejer di depan urut sesuai dengan siswa yang terlebih dahulu menemukan pasangannya. Setelah semua siswa menemukan pasangan kartu masing-masing, pasangan siswa yang pertama kali menemukan pasangan akan membacakan soal dan jawaban lalu akan memberikan penjelasan kepada siswa lain tentang soal dan jawaban dari kartu yang mereka miliki, setelah itu siswa tersebut akan 
kembali ke tempat duduk mereka masing-masing. Setelah semua siswa membacakan soal dan jawaban dari kartu mereka masing-masing serta sudah memberikan penjelasan kepada siswa lain, guru akan mengocok kartu dan membagikannya lagi kepada siswa, dengan langkah yang sama seperti pada pembagian kartu yang pertama, siswa diminta untuk menemukan pasangannya kembali, pada siklus ini, kartu dikocok lalu dibagikan kepada siswa, siswa menemukan pasangannya dilakukan sebanyak 8 kali putaran. Diakhir kegiatan guru membantu siswa untuk membuat kesimpulan dari materi yang sudah dipelajari. Pada pertemuan kedua guru memberikan soal tes yang harus dikerjakan siswa, guru menutup pelajaran dan mengucapkan salam.

\section{Observasi Siklus II}

Observasi dilaksanakan selama pelaksanaan tindakan oleh kolaborator penelitian, kolaborator mengamati berdasarkan lembar observasi yang sudah dipersiapkan oleh peneliti. Berdasarkan observasi yang dilakukan oleh observer baik pada pertemuan satu dan pertemuan kedua, pertama kali siswa menjawab salam, dilanjutkan dengan menyiapkan buku tulis dan buku paket, lalu siswa mendengarkan penjelasan guru tentang apersepsi dan motivasi, siswa mendengarkan guru menyampaikan tentang tujuan pembelajaran, materi pengantar. Lalu siswa mendengarkan penjelasan guru tentang langkah-langkah dari pembelajaran metode make a match. Siswa mendapat satu buah kartu, lalu siswa memikirkan jawabannya, lalu siswa akan berlalu mencari pasangan kartu yang dimilikinya, siswa yang sudah menemukan pasangan kartunya akan berjajar di depan kelas, setelah semua siswa menemukan pasangan kartunya, maka siswa yang paling pertama menemukan pasangan akan membacakan dan menjelaskan pasangan kartunya di depan kelas, diikuti pasangan yang lainnya, sampai habis. Setelah itu kegiatan diawali lagi dari guru membagi kartu, sampai siswa membacakan isi dari kartu pasangannya. Pada siklus ini, sebanyak 6 kali siswa melakukan kegiatan menemukan pasangan. Kegiatan selanjutnya adalah guru bersama-sama dengan siswa menyimpulkan materi pelajaran pada pertemuan itu, pada pertemuan kedua siswa mengerjakan soal tes yang diberikan oleh guru, setelah selesai mengerjakan soal. Kegiatan belajar mengajar selesai siswa lalu menjawab salam penutup dari guru.

\section{Refleksi Siklus II}

Berdasarkan hasil lembar observasi, wawancara dengan siswa dan diskusi dengan kolaborator, hasil refleksi pada siklus II baik dalam pertemuan pertama maupun pada pertemuan kedua dapat dijelaskan sebagai berikut, proses pembelajaran pada Siklus II dengan penerapan metode make a match berlangsung dengan sangat baik, siswa sangat aktif untuk mencari dan menemukan pasangan dari kartu yang mereka miliki, kesulitan yang dialami siswa dalam menemukan pasangan karena siswa belum memahami materi dapat teratasi dengan siswa membaca terlebih dahulu materi yang akan dipelajari pada pertemuan itu, siswa yang sudah menemukan pasangan dan maju ke depan, tidak hanya membacakan soal dan jawaban yang tertulis pada kartu, tetapi juga memberikan penjelasan kepada teman lain berkaitan dengan materi yang ada.

\section{Pembahasan peningkatan nilai hasil belajar siswa dengan penerapan metode make a match}

Hasil belajar siswa Siklus I

Berdasarkan hasil yang diperoleh dari tes di akhir siklus I, ketuntasan hasil belajar individu dan ketuntasan hasil belajar klasikal dapat digambarkan pada Tabel 1 dan Tabel 2.

Tabel 1. Hasil ketuntasan belajar siswa individu

\begin{tabular}{cccc}
\hline No. & Perolehan Nilai Siswa & Jumlah Siswa & Keterangan \\
\hline 1. & Siswa yang memperoleh nilai $\geq 76$ & 11 & Tuntas \\
2. & Siswa yang memperoleh nilai $<76$ & 9 & Belum tuntas \\
\hline
\end{tabular}

Tabel 2. Hasil ketuntasan belajar klasikal

\begin{tabular}{|c|c|c|c|}
\hline No. & Perolehan Nilai Siswa & Nilai & Ket \\
\hline 1. & Nilai tertinggi & 100 & \\
\hline 2. & Nilai terendah & 62 & \\
\hline 3. & Nilai rata rata kelas & 78,15 & \\
\hline 4. & Siswa mencapai nilai KKM & $55 \%$ & \\
\hline 5. & Siswa belum mencapai KKM & $45 \%$ & \\
\hline
\end{tabular}


Berdasarkan Tabel 1 menunjukkan bahwa terdapat 11 siswa yang mencapai nilai ketuntasan minimal dari semua siswa yang berjumlah 20 siswa. Siswa yang belum mencapai nilai ketuntasan minimal berjumlah 9 orang. Sedangkan berdasarkan tabel 2 nilai tertinggi yang diperoleh siswa dalam siklus I adalah 100, nilai terendah yang diperoleh siswa adalah 62, sedangkan rata-rata nilai di kelas adalah 78,15\%. Prosentase siswa yang mencapai nilai KKM di kelas sebesar 55\%, sementara siswa yang belum mencapai KKM sebanyak $45 \%$. Berdasarkan hasil yang diperoleh dari siklus I menunjukkan adanya peningkatan hasil belajar siswa dari kondisi awal yaitu kondisi dimana proses pembelajaran belum menggunakan metode Make A Match dimana pada rata-rata kelas pada kondisi awal sebesar 56,5. Hal ini menunjukkan kalau penggunakan metode pembelajaran Make A Match mampu meningkatkan hasil belajar siswa.

Hasil belajar siswa siklus II

Berdasarkan hasil yang diperoleh dari tes di akhir siklus II, ketuntasan hasil belajar individu dan ketuntasan hasil belajar klasikal dapat digambarkan dalam Tabel 3 dan Tabel 4.

Tabel 3. Hasil ketuntasan belajar siswa individu

\begin{tabular}{cccc}
\hline No & Perolehan Nilai Siswa & Jumlah Siswa & Keterangan \\
\hline 1. & Siswa yang memperoleh nilai $\geq 76$ & 15 & Tuntas \\
2. & Siswa yang memperoleh nilai $<76$ & 5 & Belum tuntas \\
\hline
\end{tabular}

Tabel 4. Hasil ketuntasan belajar klasikal

\begin{tabular}{clc}
\hline No & \multicolumn{1}{c}{ Perolehan Nilai Siswa } & Nilai \\
\hline 1. & Nilai tertinggi & 100 \\
2. & Nilai terendah & 52 \\
3. & Nilai rata rata kelas & 83,15 \\
4. & Siswa mencapai nilai KKM & $75 \%$ \\
5. & Siswa belum mencapai KKM & $25 \%$ \\
\hline
\end{tabular}

Berdasarkan Tabel 3 menunjukkan bahwa terdapat 15 siswa yang telah mencapai nilai ketuntasan minimal dari semua siswa yang berjumlah 20 siswa, Siswa yang belum mencapai nilai ketuntasan minimal berjumlah 5 orang. Berdasarkan tabel 4 menunjukkan nilai tertinggi yang diperoleh siswa dalam siklus II adalah 100, nilai terendah yang diperoleh siswa adalah 52, sedangkan nilai rata-rata kelas adalah $83,15 \%$. Prosentase siswa yang sudah mencapai KKM di kelas sebesar $75 \%$, sedangkan siswa yang belum mencapai KKM sebesar $25 \%$. Berdasarkan hasil yang diperoleh dari siklus II menunjukkan adanya peningkatan hasil belajar siswa dari siklus I. Hal ini menunjukkan dengan menggunakan metode pembelajaran make a match mampu meningkatkan hasil belajar siswa.

Hasil belajar siswa pada kondisi awal, siklus I dan siklus II

Untuk mengetahui perbandingan hasil belajar siswa dari siklus I dan siklus II, akan digambarkan dalam Tabel 5.

Tabel 5. Perbandingan nilai pada kondisi awal, siklus I dan siklus II

\begin{tabular}{clccc}
\hline No. & \multicolumn{1}{c}{ Komponen } & Kondisi Awal & Siklus I & Siklus II \\
\hline 1. & Nilai tertinggi & 90 & 100 & 100 \\
2. & Nilai terendah & 28 & 62 & 52 \\
3. & Rata-rata & 56,5 & 78,15 & 83,15 \\
4. & Prosentase ketuntasan & $17,6 \%$ & $55 \%$ & $75 \%$ \\
\hline
\end{tabular}

Berdasarkan Tabel 5 dan Gambar 1, dapat disimpulkan bahwa pencapaian nilai hasil belajar siswa dari siklus I dan siklus II mengalami peningkatan, baik dalam nilai rata-rata kelas, maupun prosentase jumlah siswa yang mencapai nilai ketuntasan minimal. Kenaikan nilai rata-rata hasil belajar siswa dari siklus I dan siklus II sebesar 5, sedangkan kenaikan prosentase ketuntasan siswa sebesar $20 \%$, hal ini disebabkan oleh beberapa faktor antara lain mengkondisikan siswa untuk terlebih dahulu mempelajari materi yang akan digunakan dalam proses pembelajaran, sehingga sebagian siswa sudah menguasai materi yang akan dipelajari, memberikan kesempatan kepada siswa untuk memberikan penjelasan berkaitan dengan materi yang ada di dalam kartu yang dimiliki, sehingga 
siswa lain akan lebih mudah memahami materi di dalam kartu yang dijelaskan oleh siswa yang lain. Berdasarkan data hasil belajar siswa dari siklus I sampai dengan siklus II, dan didukung oleh hasil penelitian yang dilakukan sebelumnya oleh Rosmala (2015) dapat disimpulkan bahwa dengan menerapkan metode pembelajaran make a match maka nilai hasil belajar siswa meningkat.

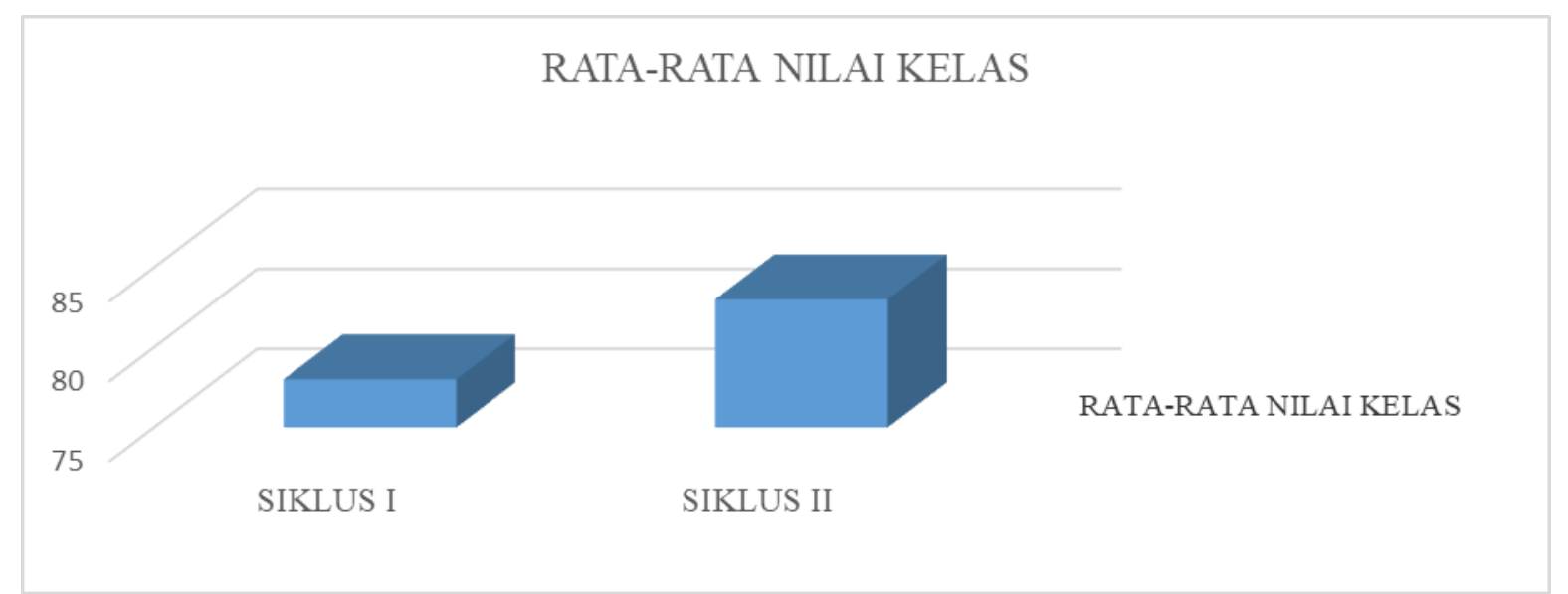

Gambar 1. Grafik Perbandingan Rata-rata hasil belajar siswa siklus I dan siklus II

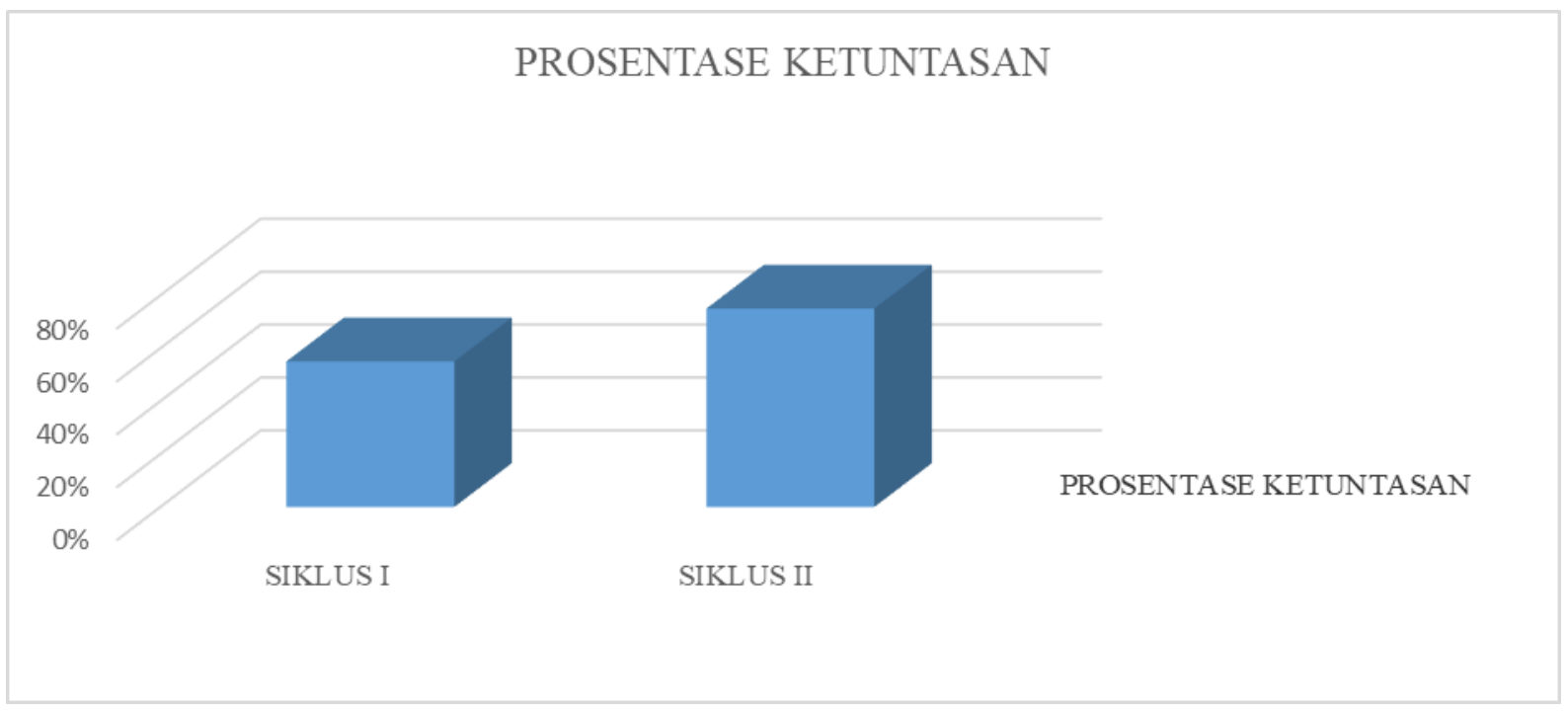

Gambar 2. Perbandingan prosentase ketuntasan minimal siklus I dan siklus II

\section{SIMPULAN}

Berdasarkan hasil penelitian dapat disimpulkan bahwa hasil belajar siswa kelas XII IPS 2 SMA Muhammadiyah 2 Yogyakarta tahun pelajaran 2016-2017 setelah diterapkannya metode pembelajaran make a match dari siklus I ke siklus II mengalami peningkatan. Hasil belajar pada siklus I dengan nilai rata-rata sebesar 78, 15 dengan nilai terendah 62 dan nilai tertinggi 100 dengan prosentase ketuntasan kelas sebesar $55 \%$. Hasil belajar siswa pada siklus II dengan nilai rata-rata sebesar 83,15 dengan nilai terendah 52 dan nilai tertinggi 100 serta prosentase ketuntasan kelas sebesar $75 \%$. Hasil belajar siswa baik secara individu maupun ketuntasan klasikal sesuai dengan indikator keberhasilan yang diinginkan peneliti. Berdasarkan hasil belajar siswa tersebut penelitian dianggap berhasil dan pembelajaran dihentikan pada siklus II.

\section{REFERENSI}

Asani, D. (2012). Efektifitas strategi pembelajaran MURDER terhadap partisipasi dan kemampuan berpikir analitis siswa SMA Negeri 1 Gombong pada mata pelajaran Biologi. Universitas Sebelas Maret.

Hermawan, H., Samsuri, S., Kurniawati, D. P., Sofyaningsih, V., \& Prasetyo, D. (2018). The use of 
the controversial public issue learning model with videos and a macromedia flash player on Civic Education. Psychology, Evaluation, and Technology in Educational Research, 1(1), 19-30. https://doi.org/10.33292/petier.v1i1.2

Nurwidia, A., Haryanto, S., \& Mulyoto, M. (2019). Keefektifan teams games tournament dan make a macth dalam meningkatkan hasil belajar matematika. Annals of Mathematical Modeling, l(1), 8-15. https://doi.org/10.33292/amm.v1i1.29

Rosmala, D. M. (2015). Implementasi model pembelajaran make a match sebagai upaya meningkatkan partisipasi dan hasil belajar siswa pada mata pelajaran kompetensi kejuruan multimediadi kelas X Multimedia SMK Negeri 6 Purworejo. Universitas Negeri Yogyakarta.

Sudjana, D. (2001). Metode dan teknik pembelajaran partisipatif. Falah Production.

Sudjana, N. (2009). Penilaian hasil proses belajar mengajar. PT Remaja Rosdakarya.

Surya, M. (2004). Psikologi pembelajaran dan pengajaran. Pustaka Bani Quraisy.

Wahyuningsih, E., Haryanto, S., \& Pardimin, P. (2019). Penerapan model pembelajaran kooperatif teknik make a match untuk meningkatkan motivasi belajar akuntansi. Teacher in Educational Research, 1(1), 35-41. https://doi.org/10.33292/ter.v1i1.8

Wena, M. (2009). Strategi pembelajaran inovatif kontemporer suatu tinjauan konseptual operasional. Bumi Aksara. 